\title{
PRODUCTION AND PARTIAL PURIFICATION OF ANTIFUNGAL CHITINASE FROM Bacillus cereus VITSD3
}

\author{
C. Subathra DEVI ${ }^{1}$; V. Mohana SRINIVASAN ${ }^{1}$; B. Archana ${ }^{1}$; Steffi Susan ROY $^{1}$; \\ S. Jemimah NAINE ${ }^{1}$ \\ 1. School of Biosciences and Technology, VIT University, Vellore, Tamil Nadu, India. subaresearch@ rediffmail.com
}

\begin{abstract}
The current work was designed to isolate and characterize chitin degrading bacteria. Among the 55 bacterial colonies isolated from 7 different soil samples, 4 isolates were capable of degrading chitinase, among which one strain VITSD3 was found to be potent. Based on the morphological, biochemical and molecular characterization of VITSD3 the isolate was confirmed as Bacillus cereus (Genbank accession number: KC961638), designated as Bacillus cereus VITSD3. The crude enzyme had a total activity of $220 \mathrm{U}$, precipitated with $44.8 \mathrm{U}$ and $22.5 \mathrm{U}$ for dialysed sample. The hydrolysed product NAG (N-Acetyl Glucosamine) from chitin was analysed by high-pressure liquid chromatography (HPLC).The molecular weight of the chitinase was determined using SDS PAGE and found to be $55 \mathrm{kDa}$. The partially purified chitinase produced from Bacillus cereus VITSD3 showed antifungal activity against Aspergillus fumigatus (18 $\mathrm{mm})$, Aspergillus niger $(6 \mathrm{~mm})$ and Aspergillus flavus $(15 \mathrm{~mm})$. Hence the investigation suggests a potential benefit of partially purified chitinase extracted from Bacillus cereus VITSD3 which will serve as an excellent antifungal potential with therapeutic use.
\end{abstract}

KEYWORDS: Chitinase. Bacillus cereus VITSD3. Antifungal activity. Chitin. Aspergillus. Partial purification.

\section{INTRODUCTION}

Chitin is well-known as an insoluble structural polysaccharide that occurs in the exoskeleton and gut linings of many insects, invertebrates such as crustaceans, protozoa, fungi and diatoms which could be hydrolysed by chitin degrading enzymes such as chitinases. (KRAMER et al., 1986). It is the second most abundant polymer and it is a monomeric protein that forms a single strand of polypeptide with molecular weight range between $21 \mathrm{kDa}$ to $70 \mathrm{kDa}$ and also known as poly 1,4 - $\quad$ (N-acetyl- $\beta$-D-glucosaminide) glycanohydrolase (JEUNIAUX et al., 1996). Recently, chitinases have receiving attention because of their possible applications for biological control also for the exploitation of natural chitinous materials (OHNO et al., 1996). Chitinases plays an important biological and physiological roles: lysis of the cell wall (separation of cells after division, hypha autolysis), nutritional requirements, morphogenetic formation (sporulation, spore germination, hyphal growth) and antagonistic actions against other microorganisms (SAHAI et al., 1993). Among their applications, chitinolytic enzymes have studied as potential antifungal agents against chitin bearing plant pathogens. The enzymes play a key role in the mechanism of parasitic entry into host cells (DAHIYA et al., 2006; MAVROMATIS et al., 2003). The fungal cell wall has a cross-linked complex structure composed of chitin, glucans, and other polymers (AGRIOS, 2005). Enzymes that hydrolyze these components play a significant role in cell wall lysis of the pathogens (ADAMS, 2005; CARSOLIO et al., 1994). The antifungal activity and highly biocompatible quality make the chitin and its derivatives particularly useful for biomedical applications such as wound healing, cartilage tissue engineering, drug delivery and nerve generation (NAGWA et al., 2004). Almost all industrial microbiology processes require the initial isolation of cultures from nature by a suitable method, followed by small-scale cultivation and optimizations (JEYANTHI et al., 2013). The discoveries of novel secondary metabolites are currently the thirst area of research (JEMIMAH NAINE et al., 2012). Chitinase is a potential antifungal agent that can be isolated from a wide range of organisms. (HORSCH et al.,1997; HARMAN et al.,2004; LI, 2006; MERZENDORFER et al.,2003; RAST et al.,2003). Further screening of microbes for enzymes, has received ever-increasing interest. Hence the main aim of the current study was to isolate and screen chitinase producing bacteria from soil samples. This study also emphasizes the antifungal activity of the chitinase from Bacillus cereus VITSD3

\section{MATERIAL AND METHODS}

\section{Isolation of chitin degrading bacteria}

Seven different soil samples were collected from Bhramapuram, Vellore and CBMR nursery, VIT, Vellore, Tamil Nadu, India. One gram of soil sample was serially diluted on colloidal chitin agar. Isolated colonies were sub cultured on nutrient agar 
plates. Pure cultures of the organisms were maintained and stored at $4{ }^{\circ} \mathrm{C}$.

\section{Colloidal chitin preparation}

Colloidal chitin was prepared by grinding chitin flakes manually and ground on a mortar and pestle for 5 minutes to fine powder and $10 \mathrm{~N} \mathrm{HCl}$ was added and kept overnight at $4^{\circ} \mathrm{C}$ with vigorous stirring. The suspension was added to $50 \%$ cold ethanol with rapid stirring and kept overnight at 25 ${ }^{\circ} \mathrm{C}$. The precipitate was collected by centrifugation at 10,000 rpm for $20 \mathrm{~min}$ and washed with sterile distilled water until the colloidal chitin becomes neutral ( $\mathrm{pH}$ 7.0). The supernatant was discarded and the pellet was stored at $4{ }^{\circ} \mathrm{C}$ till further use (PRIYA et al., 2001).

\section{Screening}

Primary screening was performed by streaking all the four bacterial isolates on colloidal chitin agar (CCA) and incubated at room temperature for 2 days. The zone of clearance due to chitin hydrolysis was recorded up to 3 days. The secondary screening was performed with the culture filtrates of selected bacterial isolates using well diffusion method. After $24 \mathrm{~h}$, the development of clear zone around the well was observed (KAVI KARUNYA et al., 2011).

\section{Morphological and biochemical characterisation}

The potent producers of chitin degrading isolate VITSD3 was further studied for its morphological and biochemical properties. The strain was identified according to the Bergey's manual of determinative bacteriology (Holt, 1994).

\section{Molecular characterisation \\ 16S rRNA gene amplification and sequencing} 16S rRNA gene sequencing of Bacillus sp was amplified using forward primer $27 \quad \mathrm{~F}$ 5'AGAGTTTGATCMTGGCTCAG3' and reverse primer $1792 \quad \mathrm{R}$ TACGGYTACCTTGTTACGACTT-3'). The sequences were subjected to homology search using BLAST programme (ALTSCHUL et al., 1990). The results were compared manually with the data in NCBI. The 16S rRNA gene sequences determined were aligned along with the sequences of the type strains using the CLUSTAL $\mathrm{W}$ program version 2.1(CHENNA et al.,2003). The phylogenetic tree was constructed by neighbourhood joining method (SAITOU et al., 1987). Individual branches in phylogenetic tree were determined by bootstrap analysis based on 1000 samplings (FELSENSTEIN et al., 1985).

\section{Chitinase production}

Colloidal chitin broth $(100 \mathrm{~mL})$ in $250 \mathrm{~mL}$ capacity Erlenmeyer flasks was inoculated with 1 $\mathrm{mL}\left(\mathrm{OD}_{600}=1.0\right)$ of potent strain Bacillus cereus VITSD3. It was incubated at $27{ }^{\circ} \mathrm{C}$ in a rotary incubator $(150 \mathrm{rpm})$ for $72 \mathrm{~h}$. Culture supernatant was collected from 2 days cultures by centrifugation at $12,000 \mathrm{~g}$ for $20 \mathrm{~min}$. The supernatant was then concentrated by ammonium sulphate precipitation.

\section{Partial purification of enzyme}

Ammonium sulphate was added to the culture supernatant in small quantities with constant stirring in order to achieve saturation. Then the supernatant was concentrated by precipitation with ammonium sulphate to $60-70 \%$ levels. The precipitates were dissolved in $50 \mathrm{mM}$ phosphate buffer ( $\mathrm{pH} 7$ ) and dialyzed over night against the same buffer. The resultant dialysates were regarded as partially purified chitinase and were used for further studies.

\section{Total protein estimation}

Total protein content of the crude, precipitated and the dialysed samples were estimated by standard Lowry's method (LOWRY et al., 1951).

\section{Enzyme assay}

The reaction mixture composed of crude enzyme solution, $1 \mathrm{~mL} 0.5 \%$ colloidal chitin in $0.1 \mathrm{M}$ citrate buffer ( $\mathrm{pH} 7.0$ ) was incubated at $37{ }^{\circ} \mathrm{C}$ in a shaking water bath for $30 \mathrm{~min}$. The reaction was terminated by adding $2 \mathrm{~mL}$ DNS reagent. The colour was developed in the tubes after $5 \mathrm{~min}$. The optical densities were measured at $575 \mathrm{~nm}$ using UV-Vis spectrophotometer (Model-Hitachi U-2800) against a blank containing $1 \mathrm{~mL}$ of 0.5 substratebuffer solution \%, $1 \mathrm{~mL}$ buffer and $2 \mathrm{~mL}$ DNS (Miller et al.,1959). Then the optical densities were compared with the control. The amount of chitinase released was determined from $\mathrm{N}$-acetyl-Dglucosamine calibration curve, where one unit of chitinase activity (U) is defined as the amount of enzyme that releases $1 \mu \mathrm{mol}$ of glucose /min under the above mentioned conditions.

\section{SDS PAGE}

The partially purified enzyme was subjected to sodium dodecyl sulfate-poly acrylamide gel electrophoresis (SDS-PAGE) with lower separating gel $(\mathrm{pH} 8.8)$, upper stacking gel $(\mathrm{pH}$ 6.8) and 12\% acrylamide concentration. A broad range protein molecular weight marker was used to compare the 
protein bands with the standards, for the confirmation of the enzyme.

\section{HPLC analysis}

The oligosaccharides obtained by enzymatic hydrolysis were analyzed by HPLC (LC-10 AT vp model). The mobile phase- acetonitrile: water $(70: 30 \mathrm{v} / \mathrm{v})$ at the flow rate of $1 \mathrm{~mL} / \mathrm{min}$ and detected at $210 \mathrm{~nm}$ with $\mathrm{NH}_{2} \mathrm{P}_{50}-4 \mathrm{E}$ column. The retention times for the peaks detected in the crude samples of hydrolytic products were compared (CHANG et al., 2003).

\section{Antifungal activity}

The partially purified chitinase enzyme was checked for antifungal activity against Aspergillus niger MTCC No:872; Aspergillus fumigates MTCC No:8877; Aspergillus flavus MTCC No:8790.The fungal cultures were obtained from Microbial culture collection, IMTECH, Chandigarh, INDIA.
Agar well diffusion assay was performed on potato dextrose agar. The plates were incubated for 5 days at $30{ }^{\circ} \mathrm{C}$. After incubation the zone of inhibition was measured.

\section{RESULTS AND DISCUSSION}

\section{Isolation and screening}

In the present study, a total of fifty five organisms were isolated from seven different soil samples. The preliminary screening revealed four isolates were capable of degrading chitinase, among which one strain VITSD3 was found to be potent. Chitinolytic bacteria isolated from soil were identified by the formation of distinct clearing zones on the substantially darker background of the medium within 2-3 days of incubation. All the four strains were subjected to preliminary screening which revealed the potential producers of chitinase (Figure1).

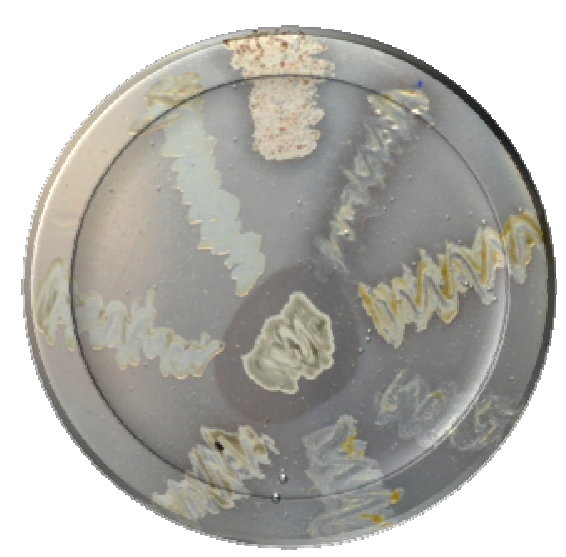

Figure1. Screening for chitinase production on colloidal chitin agar

Interestingly, the isolate obtained from the rhizosphere soil VITSD3 remarkably hydrolyzed the colloidal chitin and produced a prominent and maximum clear zone on CCA plate. The culture filtrate of the potent isolate produced a clear zone of $13 \mathrm{~mm}$. The morphological characteristics of the isolate VITSD3 was found to be whitish colored colonies with irregular margin and an opaque density, convex elevation with a lobate configuration on nutrient agar. Based on the gram staining results the VITSD3 strain was found to be gram positive rod shaped bacilli in singles and pairs( Figure 2). Based on the isolate VITSD3 was identified as Bacillus sp. (Table 1)

The adoption of colloidal chitin in the media has provided easier and more accurate screening of chitinolytic Bacillus cereus VITSD3. These finding coincides with previous studies that suggest employing colloidal chitin as sole carbon source for highest chitinase production (PRIYA et al., 2011).

\section{Molecular characterisation}

Sequence results of $16 \mathrm{~S}$ rRNA was exported to the database and checked for the homologous alignment. Based on the alignment results, strain VITSD3 was found as Bacillus cereus which showed $99 \%$ similarity. The strain name was designated as Bacillus cereus VITSD3. The partial 16S rRNA sequence was deposited in Gen Bank under the accession number KC961637. The phylogenetic tree based on 16S rRNA of the strain Bacillus cereus VITSD3 is shown in Figure 3. 


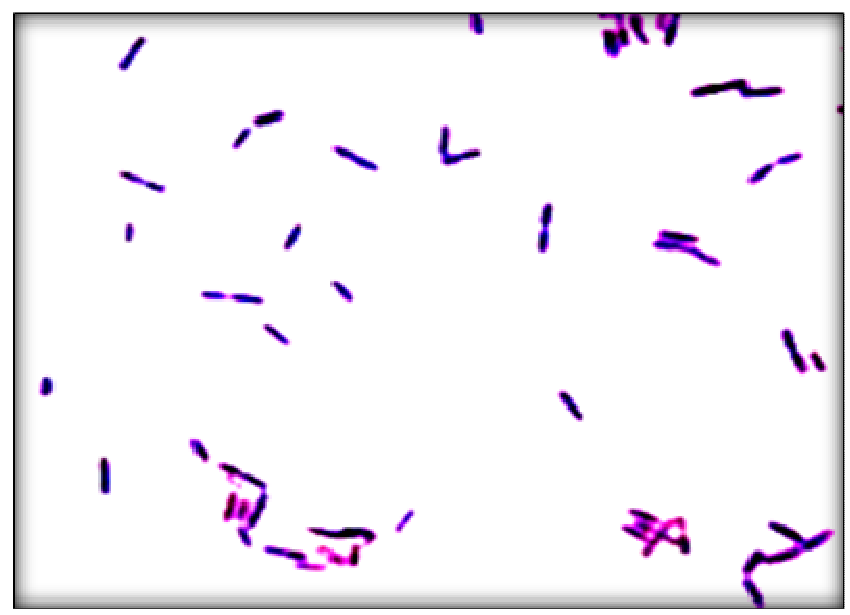

Figure 2. Microscopic observation of VITSD3

Table.1 Biochemical and morphological characterisation of the isolate Bacillus cereus VITSD3

\begin{tabular}{|c|c|c|c|c|c|c|c|c|c|c|c|c|}
\hline $\begin{array}{c}\text { Gram } \\
\text { staining }\end{array}$ & Motility & $\begin{array}{l}\text { Methyl } \\
\text { red }\end{array}$ & $\begin{array}{c}\text { Voges- } \\
\text { Proskauer }\end{array}$ & Indole & Glucose & Adonitol & Arabinose & Sorbitol & Mannitol & Rhamnose & Sucrose & Fructose \\
\hline+ & + & + & - & - & + & - & - & - & - & - & - & + \\
\hline
\end{tabular}




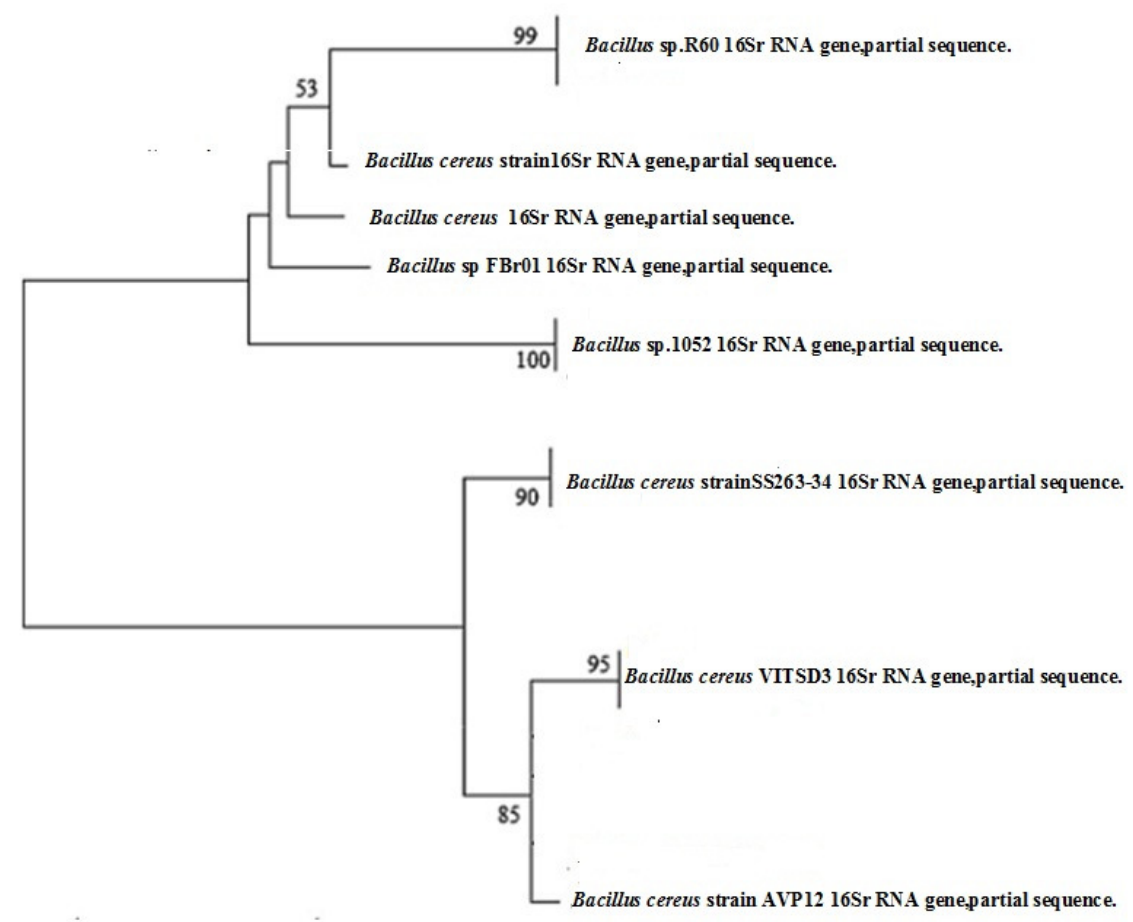

Figure 3. Phylogenetic tree of Bacillus cereus VITSD3

\section{Total protein estimation and enzyme assay}

Total protein estimation of crude enzyme, precipitated and dialyzed sample showed differences in OD readings was due to its variable presence of total protein content. The concentration of N-Acetyl glucosamine in the sample was derived using different concentration of NAG. The specific enzyme activity of the crude enzyme was found to be $3.2 \mathrm{U} / \mathrm{mg}$ whereas the precipitated was determined as $12.3 \mathrm{U} / \mathrm{mg}$ and $13.2 \mathrm{U} / \mathrm{mg}$ for dialysed sample. The partially purified dialysed enzyme showed the yield of $24.2 \%$ with the purification fold of 9.8 (Table 2).

Table .2. Chitinase activity and yield of enzyme from Bacillus cereus VITSD3

\begin{tabular}{cccccc}
\hline Enzyme & $\begin{array}{c}\text { Total } \\
\text { protein } \\
(\mathrm{mg})\end{array}$ & $\begin{array}{c}\text { Total } \\
\text { activity } \\
(\mathrm{U})\end{array}$ & $\begin{array}{c}\text { Specific } \\
\text { activity(U/mg) }\end{array}$ & Yield\% & Purification fold \\
\hline $\begin{array}{c}\text { Crude } \\
\text { Supernatant }\end{array}$ & 69 & 220 & 3.2 & 100.0 & 1.0 \\
$\begin{array}{c}\text { Ammonium } \\
\text { sulphate }(60- \\
70 \%)\end{array}$ & 3.64 & 44.8 & 12.3 & 25.9 & 4.9 \\
$\begin{array}{c}\text { Dialyzed } \\
\text { enzyme }\end{array}$ & 1.71 & 22.5 & 13.2 & 24.2 & 9.8 \\
\hline
\end{tabular}

Similar results were reported in the previous studies, the protein content extracted from sample was found to be $1010 \mathrm{mg}$ with a specific activity of 0.063, 0.016 and $0.053 \mathrm{AU} / \mathrm{mg}$ (KHALID THABIT et al.,2013).

\section{SDS-PAGE}

The molecular weight of the partially purified chitinase was found to be $55 \mathrm{KDa}$ and hence it confirms the chitinase produced by Bacillus cereus VITSD3 (Figure 4). 


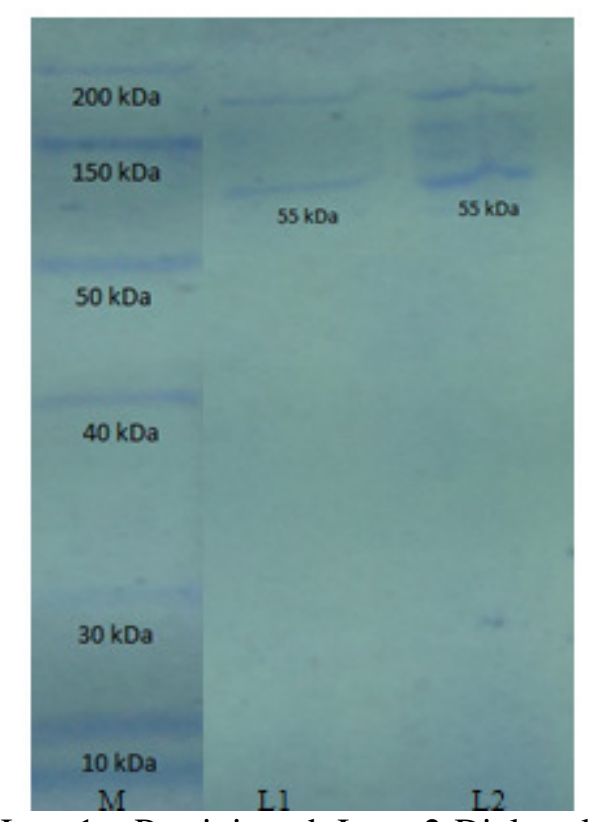

M-Marker; Lane1 - Precipitated; Lane 2-Dialysed

Figure 4. SDS-PAGE of partially purified chitinase from Bacillus cereus VITSD3

Chitinase produced by some $B$. thuringiensis strain had a molecular weight of about $61 \mathrm{kDa}$ (NAGWA et al.,2004). Similar results were indicated by the other chitinases using SDS-PAGE analysis of enzyme from Bacillus sp around 2580kDa (DHAR et al., 2010).

\section{HPLC analysis}

HPLC analysis revealed the presence of

NAG (N-Acetyl Glucosamine) from chitin hydrolysates. The retention time of the principal peak was observed at $3 \mathrm{~min}$ (Figure 5). The previous reports support the present findings (JEYANTHI et al.,2013). Similar results were obtained for the products. The partially purified chitinase from the enzyme precipitated sample showed the principal peak at $3.17 \mathrm{~min}$ which indicates the presence of chitinase.

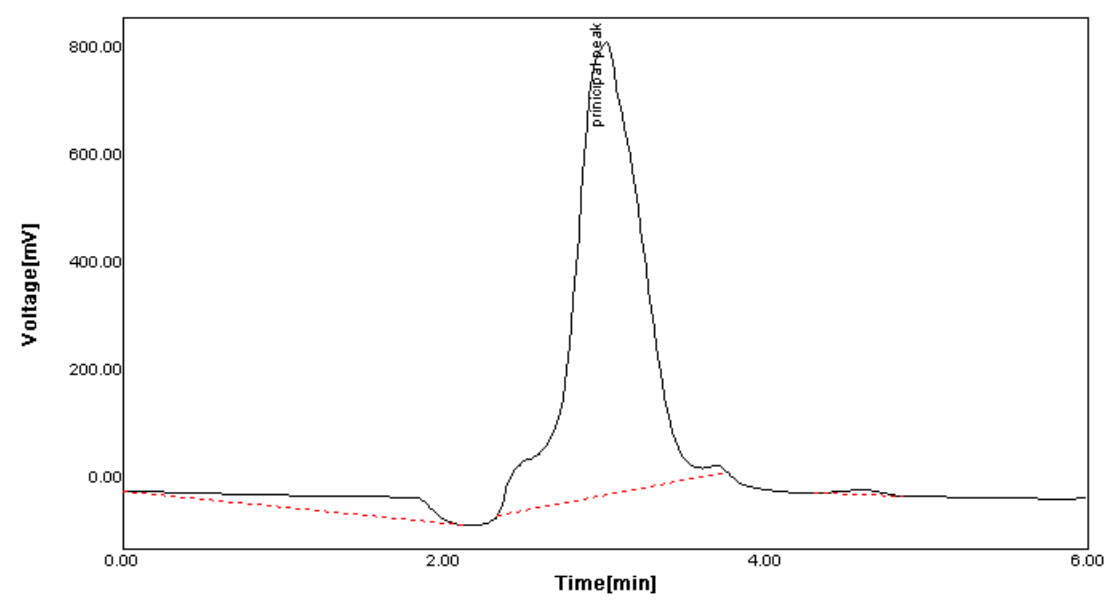

Figure 5. HPLC chromatogram of the hydrolysed product

\section{Antifungal activity}

Antifungal activity of the partially purified chitinase was determined. It showed inhibitory activity against Aspergillus fumigatus $(18 \mathrm{~mm})$, Aspergillus niger (6 mm) and Aspergillus flavus (15 $\mathrm{mm}$ ).(Figure 6). The relevant data reported by the chitinase inhibition against Aspergillus niger (7 $\mathrm{mm}$ ), Aspergillus flavus (5 $\mathrm{mm}$ ) (MUHAMAD, 2009). The present result is supported by the previous literature as the chitinolytic bacteria are active against the fungal pathogens (SID AHMED et al., 2003; DE BOER et al.,1999). 


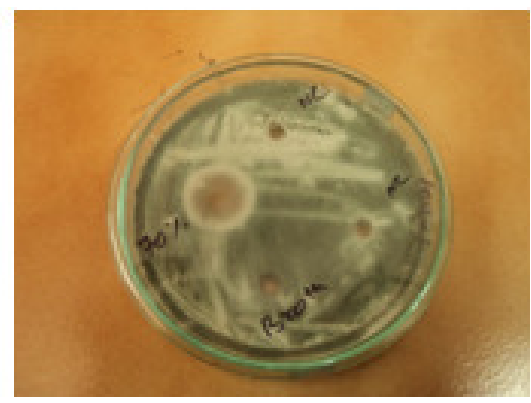

A

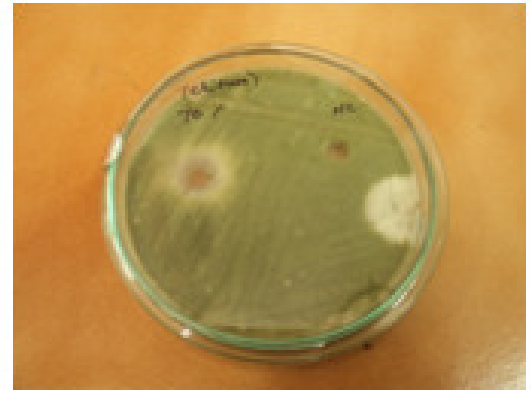

B

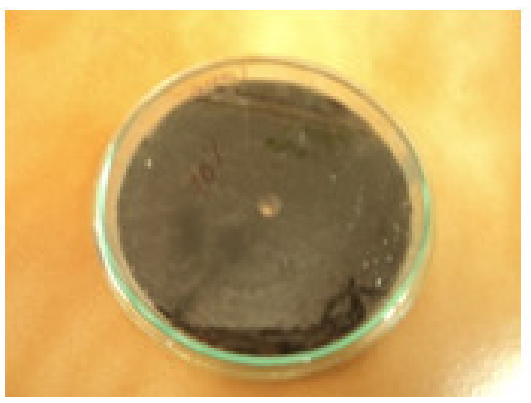

$\mathrm{C}$

Figure 6. Antifungal activity of partially purified chitinase against fungal pathogens (A) Aspergillus fumigatus (18 mm), (B) Aspergillus flavus $(15 \mathrm{~mm})(C)$ Aspergillus niger $(6 \mathrm{~mm})$

Recently, chitinases have been receiving attention because of their possible application for biological control and gaining importance for their biotechnological applications as it is biodegradable with various applications in the environmental, agricultural, food technology and cosmetics. Despite the potential applications of chitinase, the most promising future applications in therapy of fungal diseases and potential as therapeutic of antifungal drugs. Although chitinase have been isolated and characterized from a wide variety of sources, it is still important to screen for new sources for production of chitinase with more economical values and enhanced properties to expand their usefulness. Hence the study is unique when compared to previously reported studies on chitinase producing on the related genera. Pilot scale production and enzyme kinetics of chitinase is yet to be adopted for maximum production.

\section{ACKNOWLEDGEMENT}

We are greatly indebted to Vellore Institute of Technology for the constant encouragement, help and support for extending necessary facilities.

RESUMO: O presente trabalho atual foi delineado para isolar e caracterizar bactérias degradadoras de quitina. Entre as 55 colónias bacterianas isoladas a partir de 7 amostras de solo diferentes, quatro isolados foram capazes de degradar quitinase, entre os quais uma estirpe, VITSD3, mostrou-se potente. Com base na caracterização morfológica, bioquímica e molecular de VIT D3 a soluto foi confirmada como Bacillus cereus (número de acesso Genbank: KC961638), designada como Bacillus cereus VITSD3. A enzima bruta tinha uma actividade total de 220 L, precipitou-se com 44,8 L e 22,5 L de amostra dialisada. O produto hidrolisado NAG (N-acetil-glucosamina) a partir de quitina foi analisado por cromatografia líquida de alta pressão (HPLC) .O peso molecular da quitinase foi determinado, utilizando-se SDS-PAGE e verificou-se ser $55 \mathrm{kDa}$. A quitinase parcialmente purificada produzida a partir de Bacillus cereus VITSD3 mostrou actividade antifúngica contra Aspergillus fumigatus $(18 \mathrm{~mm})$, Aspergillus niger $(6 \mathrm{~mm})$ e Aspergillus flavus (15 $\mathrm{mm})$. Por isso, a investigação sugere um potencial benefício de quitinase parcialmente purificada extraída de Bacillus cereus VITSD3 o que poderá servir como um excelente potencial antifúngico para uso terapêutico.

PALAVRAS-CHAVES: Quitinase; Bacillus cereus VITSD3. Atividade antifúngica.; Aspergillus. Purificação parcial.

\section{REFERENCES}

ADAMS, D. L. Fungal cell wall chitinases and glucanase. Microbiol, v. 150, p. 2029-2035. 2004. http://dx.doi.org/10.1099/mic.0.26980-0

AGRIOS, G. N. Plant pathology. 5th edn. Elsevier Academic Press. p. 922. 2005.

ALTSCHUL, S. F.; GISH, W.; MILLER, M.; MYERS, E. W.; LIPMAN, D. J. Basic local alignment search tool. J Mol Biol, v. 215, n. 3, p. 403-410. 1990. http://dx.doi.org/10.1016/S0022-2836(05)80360-2 
CARSOLIO, C.; GUTIERREZ, A.; JIMENEZ, B.; MONTAGU, M. V.; HERRERA ESTRELLA, A. Characterization of ech-42, a Trichoderma harzianum endochitinase gene expressed during mycoparasitism. Proc Natl Acad Sci U S A, v. 91, p. 10903-10907. 1994. http://dx.doi.org/10.1073/pnas.91.23.10903

CHANG, W.T.; CHEN, C. S.; WANG, S. L. An Antifungal Chitinase Produced by Bacillus cereus with Shrimp and Crab Shell Powder as a Carbon Source. Current Microbiol, v. 47, p. 102-108. 2003. http://dx.doi.org/10.1007/s00284-002-3955-7

CHENNA, R.; SUGAWARA, H.; KOIKE, T.; LOPEZ, R.; GIBSON, T. J.; HIGGINS, D. G.; THOMPSON, J. D. Multiple sequence alignment with the Clustal series of programs. Nucleic Acids Res, v. 31, p. 3497-3500. 2003. http://dx.doi.org/10.1093/nar/gkg500

DAHIYA, N.; TEWARI, R.; HOONDAL, G. S. Biotechnological aspects of chitinolytic enzymes: a review. Appl Microbiol Biotechnol, v. 71, p. 773-782. 2006. http://dx.doi.org/10.1007/s00253-005-0183-7

DE BOER, W.; KLEIN GUNNEWIEK, P. J. A.; LAFEBER, P.; JANSE, J. D.; SPIT, B. E.; WOLDENDORP, J. W. C. Antifungal properties of chitinolytic dune soil bacteria. Soil Biol. Biochem, v. 30, p. 193-203.1999.

DHAR, P.; KAUR, G. Effects of carbon and nitrogen sources on the induction and repression of chitinase enzyme from Beauveria bassiana isolates. Afr J Biotechnol, v. 9, n. 47, p. 8092-8099. 2010.

FELSENSTEIN, J. Confidence Limits on Phylogenies: An Approach Using the Bootstrap. Evolution, v. 39 n. 4, p. 78-791.1985.

HARMAN, G. E.; HOWELL, C. R.; VITERBO, A.; CHET, I.; LORITO, M. Trichoderma speciesopportunistic, avirulent plant symbionts. Nat Rev Microbiol, v. 2, p. 43-56. 2004.

http://dx.doi.org/10.1038/nrmicro797

HOLT, J. G. Group 17 Gram-Positive Cocci: Bergey's Manual of Determinative Bacteriology, ed 9th. Baltimore: William \& Wilkins. pp. 529-541. 1994.

HORSCH, M.; MAYER, C.; SENNHAUSER, U.; RUST, D. M. b-NAcetylhexosaminidase: a target for the design of antifungal agents. Pharmacol Ther, v. 76, p. 187-218. 1997. http://dx.doi.org/10.1016/S01637258(97)00110-1

JEMIMAH NAINE, S.; NASIMUNISLAM, N.; VAISHNAVI, B.; MOHANASRINIVASAN, V.; SUBATHRA DEVI, C. Isolation of soil actinomycetes inhabiting amirithi forest for the potential source of bioactive compounds. Asian J Pharm Clin Res, v. 5, n. 4, p. 189-192. 2012.

JEUNIAUX, C. Chitinases. In E. F. Neufeld and V. Ginsburg (eds.), Complex Carbohydrates. Methods in Enzymology. Academic Press, Inc, New York, v. 8, pp. 644-650.1996. http://dx.doi.org/10.1016/00766879(66)08117-5

JEYANTHI REBECCA, L.; SUSITHRA, G.; SHARMILA, S.; MERINA, P. D. Isolation and screening of chitinase producing Serratia marcescens from soil. J Chem Pharm Res, v. 5, n. 2, p. 192-195.2013.

KAVI KARUNYA, S.; REETHA, D.; SARANRAJ, P.; JOHNMILTON, D. Optimization and purification of chitinase produced by Bacillus subtilis and its antifungal activity against plant pathogens. Int J Pharm Biol Arch,v. 2, n. 6, p. 680-1685.2011.

KHALID, THABIT.; SUMAIA, M AL-GHURIBI.; FATIMA, N AL-ASWADI. DNA Sequence Comparisons Using Codons. Arab J Sci Eng. doi :10.1007/s13369-013-0760. 2013.

KRAMER, K. J.; KOGA, D. Insect chitin: physical state, synthesis, degradation and metabolic regulation. Insect Biochem, v. 16, p. 851-877. 1986. http://dx.doi.org/10.1016/0020-1790(86)90059-4 
LI, C. D. Review of fungal chitinases. Mycopathol, v. 161, p. 345-360.2006.

LIU, M.; CAI, Q. X.; LIU, H. Z.; ZHANG, B. H.; YAN, J. P.; YUAN, Z. M. Chitinolytic activities in Bacillus thuringiensis and their synergistic effects on larvicidal activity. J Appl Microbiol, v. 93 n. 3, p. 374-9.2002.

LOWRY, O. H.; ROSSEN BROUGH, N. J.; FARR, A. L.; RANDALL, R. J. Protein measurement with Folin Phenol reagent. J Biol Chem, v. 193, p. 265-275.1951.

MAVROMATIS, K.; WOO, MLSL.; BOURIOTIS, V. Mode of action and antifungal properties of two coldadapted chitinases. Extremophiles, v. 7, p. 385-390. 2003. http://dx.doi.org/10.1007/s00792-003-0338-3

MERZENDORFER, H.; ZIMOCH, L. Chitin metabolism in insects: structure, function and regulation of chitin synthases and chitinases. J Exp Biol, v. 206, p. 4393-4412. 2003. http://dx.doi.org/10.1242/jeb.00709

MILLER, G. L. Use of dinitrosalicylic acid for determination of reducing sugar. Analytical chem, v. 31, p. 426-428.1959.

MUHAMAD, FAIS.; BIN, MOHD ARSHAD. Purification and Characterization of Chitinase produced by Actinomycetes. Malaysia: Universiti Teknologi. 2009.

NAGWA, H.; FODA.; HANAN, M.; ELLAITHY MINA, I.; TADROS. Optimization of Biodegradable sponges as controlled release drug matrices. I. Effect of moisture level on chitosan sponge mechanical properties. Drug Development Indus Pharm, v. 30 n. 4, p. 369-379. 2004. http://dx.doi.org/10.1081/DDC120030931

OHNOT ARMAND, S.; HATA, T.; NIKAIDOU, N.; HENRISSAT, B.; MITSUTOMI, M.; WATANABE, T. A modular family 19 chitinase found in prokaryotic organism Streptomyces griseus HUT 6037. Bacteriol, v. 178, p. 5065-5070.1996.

PRIYA, C. S.; JAGANNATHAN, N.; KALAICHELVAN, P. T. Production of chitinase by streptomyces hygroscopicus vmch2 by optimization of cultural conditions. Int J Pharm Biol Sci, v. 2, n. 2, p. 210. 2011.

PRIYA, C. S.; JAGANNATHAN, N.; KALAICHELVAN, P. T. Production of chitinase by Streptomyces Hygroscopicus VMCH2 by optimisation of cultural conditions. Int J Pharm Bio Sci, v. 2, n. 2, p. 210-219. 2011.

RAST, D, R.; BAUMGARTNER, D.; MAYER, C.; HOLLENSTEIN, G. O. Cell wall-associated enzymes in fungi. Phytochem, v. 64, p. 339-366.2003.

SAHAI, A. S.; MANOCHA, M. S. Chitinases of fungi and plants: their in morphogenesis and host-parasite involvement interaction. FEMS Microbiol Rev, v. 11, p. 317-338. 1993 . http://dx.doi.org/10.1111/j.15746976.1993.tb00004.x

SAITOU, N.; NEI, M. The neighbor-joining method: a new method for reconstructing phylogenetic trees. Mol Biol Evol, v. 4, p. 406-425. 1987.

SAKAI, K.; YOKOTA, A.; KUROKAWA, H.; WAKAYAMA, M.; MORIGUCHI, M. Purification and characterization of three thermostable endochitinases of Bacillus noble strain $\mathrm{MH}-1$ isolated from chitin containing compost. App Environ Microbiol, v. 64, n. 9, p. 3340-3497.1998.

SID AHMED, A.; P EREZ, C.; EZZIYYANI, M.; CANDELA, M.E. Effect of chitin on biological control activity of Bacillus spp. and Trichoderma harzianum against root rot disease in pepper (Capsicum annuumliu) plants. Euro J Plant Pathol, v. 109, p. 633-637. 2003. http://dx.doi.org/10.1023/A:1024734216814 